\section{Nauplius}

The Journal OF The

Brazilian Crustacean Society

e-ISSN 2358-2936

www.scielo.br/nau www.crustacea.org.br

\title{
Larval development of Libinia rhomboidea Streets, 1870 (Crustacea: Decapoda: Brachyura: Majoidea) under laboratory conditions
}

\author{
Sergio Cházaro-Olvera' ${ }^{1}$ (D) orcid.org/0000-0002-0667-0043 \\ Claudia Carmona-Osalde² (D) orcid.org/0000-0002-0079-5005 \\ Miguel Rodríguez-Serna² (D) orcid.org/0000-0002-2588-4194
}
1 Laboratorio de Crustáceos, Facultad de Estudios Superiores Iztacala, Universidad Nacional Autónoma de México. Av. de los Barrios No.1, Los Reyes Iztacala, C.P. 54090, Tlalnepantla, Estado de México, México.
sco E-mail: chazaro@campus.iztacala.unam.mx
2 Laboratorio de Biotecnología Acuícola, Unidad Multidisciplinaria de Docencia e Investigación, Unidad Sisal, Facultad de Ciencias, Universidad Nacional Autónoma de México (UNAM). Puerto de Abrigo s/n, CP 97355, Sisal, Yucatán, México. cco Email: turix_cco@yahoo.com.mx MRS Email: mrserna@ciencias.unam.mx

ZOOBANK: http://zoobank.org/urn:lsid:zoobank.org:pub:4334591B-37D7-480BB815-BC7341A46404

\section{ABSTRACT}

In this study, the larval development of Libinia rhomboidea Streets, 1870 under laboratory conditions is described and compared with the description of Libinia spinosa $\mathrm{H}$. Milne Edwards in Guérin, 1832, Libinia dubia H. Milne Edwards, 1834, and Libinia emarginata Leach, 1815 published by other authors. The ovigerous females collected released larvae asynchronously. Two zoeas and one megalopa stage were obtained. Larval development required 13 to 14 days at $20.5-22.0^{\circ} \mathrm{C}$ and $32-35$ psu of salinity. The differences in L. rhomboidea with respect to the other three species are the following: in the first zoea, the total length and carapace length were greater and the number of setae on the basial endite of the maxillula was different; in the second zoea the size of the endopod and the number of setae on the scaphognathite of the maxilla were greater; in the megalopa, the total length and carapace length were both greater, while the number of setae on the scaphognathite of the maxilla was less. A great similarity between L. rhomboidea and L. dubia was found; however, it is possible to distinguish

CORRESPONDING AUTHOR Sergio Cházaro-Olvera chazaro@campus.iztacala.unam.mx

SUBMITTED 19 November 2019 ACCEPTED 5 May 2020 PUBLISHED 7 August 2020

DOI 10.1590/2358-2936e2020032

\section{(c) BY}

All content of the journal, except where identified, is licensed under a Creative Commons attribution-type BY.

Nauplius, 28: e2020032 the larval morphology of $L$. rhomboidea from the three species compared.

\section{KEYWORDS}

Gulf of Mexico, larval description, megalopa, spider crab, zoea 


\section{INTRODUCTION}

The spider crabs of the superfamily Majoidea have symbiotic relationships throughout their life history. Larvae and juveniles are associated with scyphozoan jellyfish (Gonçalves et al., 2016) and adults can be hosts of algae, sponge and cnidarian epibionts, thus expanding the distribution of these sessile organisms while obtaining protection (camouflage) (Nogueira and Haddad, 2005; Hultgren and Stachowicz, 2011).

In particular, majid crabs of the genus Libinia Leach, 1815 are marine crustaceans that are naturally distributed throughout the coast of the Gulf of Mexico (Felder et al., 2009). In addition to the ecological importance of spider crabs, for many years they have constituted a very important resource for Yucatán people due to their use as bait in octopus fishing (Zaldivar-Rae et al., 2009).

In recent years, since 2000, the collapse of the African octopus fisheries has led to an opening of international markets for the Yucatecan octopus, which has increased exploitation of the crabs as bait; so the local population of Libinia dubia H. Milne Edwards, 1834 has diminished (CONABIO, 2010). This may have allowed Libinia rhomboidea Streets, 1870 to expand the distribution of its populations along the coasts of Yucatan, where its capture has increased (Carmona-Osalde et al., 2018).

Species of the genus Libinia go through five phases of color change in the egg during their development (Carmona and Rodríguez, 2012). Complete larval development comprises two zoea stages and a megalopa stage and requires 9 - 30 days, according to species (Yang, 1967; Boschi and Scelzo, 1968; Sandifer and van Engel, 1971).

So, of the four species of the genus Libinia with distributions in the SW and SE of the Gulf of Mexico (Felder et al., 2009), the full larval descriptions of $L$. dubia (see Sandifer and van Engel, 1971) and Libinia emarginata Leach, 1815 (Johns and Lang, 1977) are known. However, the descriptions of Libinia erinacea (A. Milne-Edwards, 1879) larvae (Yang, 1967) are still incomplete and that of L. rhomboidea is lacking.

The spider crab L. rhomboidea is currently distributed in the north of the Yucatan Peninsula, on the coast of Yucatan and is historically found from Massachusetts, United States of America, to
Cuba (Williams et al., 1977). In the present study the larval stages of L. rhomboidea reared under laboratory conditions are described and compared with other larvae from the genus Libinia from the Atlantic.

\section{Materials and Methods}

\section{Collection of experimental organisms}

Crabs were collected from January to May 2018, using artisanal bottom shrimp traps that were $0.8 \mathrm{~m}$ long, $0.50 \mathrm{~m}$ wide and $0.4 \mathrm{~m}$ high at $20 \mathrm{~m}$ depth, with fish as bait. The collections were carried out within the coordinates $21^{\circ} 19^{\prime}-21^{\circ} 10^{\prime} \mathrm{N}$ and $90^{\circ} 09^{\prime}-90^{\circ} 02^{\prime} \mathrm{W}$, located off the coast of the Port of Sisal, Yucatán. One hundred individuals of $L$. rhomboidea were obtained and were identified to species level by means of identification keys and the support of the members of the National Crustacean Collection of the Institute of Biology of the Universidad Nacional Autonoma de Mexico. Later, females were added to this collection with the number CNCR: 34650. They were sexed and kept at the Unidad Multidisciplinaria de Docencia e Investigación (UMDI) aquatic biotechnology laboratory. Forty ovigerous females with eggs in stage $\mathrm{V}$ development (Carmona and Rodríguez, 2012) were separated from the sample and placed individually in $20 \mathrm{~L}$ aquariums with filtered natural seawater in the laboratory under controlled conditions of temperature $\left(20.5-22.0^{\circ} \mathrm{C}\right)$, salinity $(32-35 \mathrm{psu})$ and constant aeration. The females were fed with Camaronina ${ }^{\circledR}$ $25 \%$ protein; the unconsumed food was eliminated with a siphon. Hatching occurred after $60 \pm 12 \mathrm{~h}$ and immediately some zoea I larvae were collected for descriptive purposes.

\section{Management, maintenance and description of larvae}

Once the larvae were released, they were transferred to $5 \mathrm{~L}$ plastic aquariums, at a density of 60 larvae $\mathrm{L}^{-1}$. The conditions of temperature, salinity, and constant aeration were similar to that of the females and they were subject to a natural light-dark regime (12:12 L:D ratio). The zoea I and zoea II were fed ad libitum with $5 \mathrm{ml}$ of each microalgae (Chaetoceros Ehrenberg, C.G. 1844 and Tetraselmis Stein F, 1878, Spirulina Gomont, 1892) and fresh Artemia Leach, 1819 nauplii (10 nauplii $\left.\mathrm{mL}^{-1}\right)$. The megalopae were fed on Artemia sp. metanauplii. 
Each aquarium was checked daily to remove the exuvia and dead larvae; later, the water was changed, and food was supplied. The zoeae and megalopae were preserved in $70 \%$ ethanol.

Five zoeae and megalopa were examined, dissected and illustrated in detail (Clark and Cuesta, 2015) using a camera lucida, a Motic SMZ-168 and BA-210 microscope. Measurements were made in millimetres $(\mathrm{mm})$ with a digital camera and the software Omax 14MP USB 3.0. Illustrations were completed using Corel Draw v. 12.

Descriptions of the morphological characters were made following Clark et al. (1998) and Clark and Cuesta (2015). Measurements of total length (TL), cephalothorax length (CL), cephalothorax width (CW), dorsal spine length (DL), rostral spine length (RL), length from tip of rostral spine to tip of dorsal spine (RDL) were made. The average \pm standard deviation of each measurement was obtained.

\section{Results}

\section{Development}

Zoea 1 moulted to zoea 2 in $4 \pm 1$ days, zoea 2 moulted to megalopa at $5 \pm 1$ days, the latter moulted to the first crab at $4 \pm 1$ days.

\section{Larval Description}

Two zoeal stages and one megalopa stage were obtained during the rearing period.

Libinia rhomboidea Streets, 1870

Synonymy. Libinia inflata Streets, 1870

First zoea (Figs. 1, 2)

Size. $\mathrm{TL}=2.71 \pm 0.02 \mathrm{~mm} ; \mathrm{CL}=0.83 \pm 0.02 \mathrm{~mm}$; $\mathrm{CW} 0.70 \pm 0.01 \mathrm{~mm} ; \mathrm{DL}=0.50 \pm 0.01 \mathrm{~mm} ; \mathrm{RL}=0.10$ $\pm 0.01 \mathrm{~mm} ; \mathrm{RDL}=1.45 \pm 0.01 \mathrm{~mm}$.

Cephalothorax (Fig. 1A, B). Spherical, dorsal spine well developed, rostral spine length shorter than the length of the antenna curved towards the ventral margin, without lateral spines. One pair of setae between the dorsal spine and the eyes. A pair of plumose setae at the antero-ventral margin and three setae at the postero-ventral margin. Eyes sessile.

Pleon (Fig. 1A, C). Five pleonites; pleonite 2, with dorsolateral processes; pleonites 3 - 5 with short lateral processes; pleonites $2-5$ with a pair of posterodorsal setae. Telson bifurcated, posterior margin with 3 pairs of serrulate setae. Furcae only with lateral spines.

Pleopods (Fig. 1C). Absent.

Antennule (Figs. 1A, D). Uniramous. Endopod absent. Exopod unsegmented with 4 terminal aesthetascs ( 2 long and 2 smaller) and 1 short simple terminal seta.

Antenna (Fig. 1A, E). Biramous. Protopod well developed, spinous process armed with strong spines arranged in two lines. Endopod bud medially on protopod. Exopod bud elongated and tapering to a point, 2 subterminal spines shorter than protopod.

Mandible (Fig. 1F). Antero-ventral margin with 5 teeth; 1 tooth on postero-median margin. Palp absent.

Maxillule (Fig. 2A). Coxal endite with seven (five terminal and two subterminal) sparsely plumose setae. Basial endite with 5 sparsely plumose terminal setae and 2 plumodenticulate subterminal setae. Endopod 2-segmented, proximal segment with one sparsely plumose seta, distal segment with 5 sparsely plumose terminal setae.

Maxilla (Fig. 2B). Coxal endite bilobed with 4 +3 plumose setae. Basial endite bilobed with $5+4$ sparsely plumose setae. Endopod unsegmented, with 4 sparsely plumose terminal setae and microtrichia on external margins. Scaphognathite with 9 plumose marginal setae and a plumose apical tip.

First maxilliped (Fig. 2C). Coxa without setae. Basis with 9 mesial sparsely plumose setae arranged $2+2+3+3$ (proximal to distal). Endopod 5-segmented with 3, 2, 1, 2, 5 sparsely plumose setae. Exopod 2 -segmented, distal segment 4 long plumose, natatory, terminal setae.

Second maxilliped (Fig. 2D). Coxa without setae. Basis 3 long sparsely plumose setae arranged $1+1+1$. Endopod 3-segmented, 0, 1, 4 sparsely plumose setae. Exopod 2-segmented, 4 long plumose, natatory, terminal setae.

Third maxilliped (Fig. 1A). Rudimentary.

Pereiopods (Fig. 1A). Rudimentary.

\section{Second zoea (Figs. 3, 4)}

Size: $\mathrm{TL}=2.92 \pm 0.09 \mathrm{~mm} ; \mathrm{CL}=1.07 \pm 0.05 \mathrm{~mm}$; $\mathrm{CW}=0.93 \pm 0.05 \mathrm{~mm} ; \mathrm{DL}=0.53 \pm 0.02 \mathrm{~mm} ; \mathrm{RL}$ $0.27 \pm 0.02 \mathrm{~mm} ; \mathrm{RDL}=1.61 \pm 0.05 \mathrm{~mm}$. 


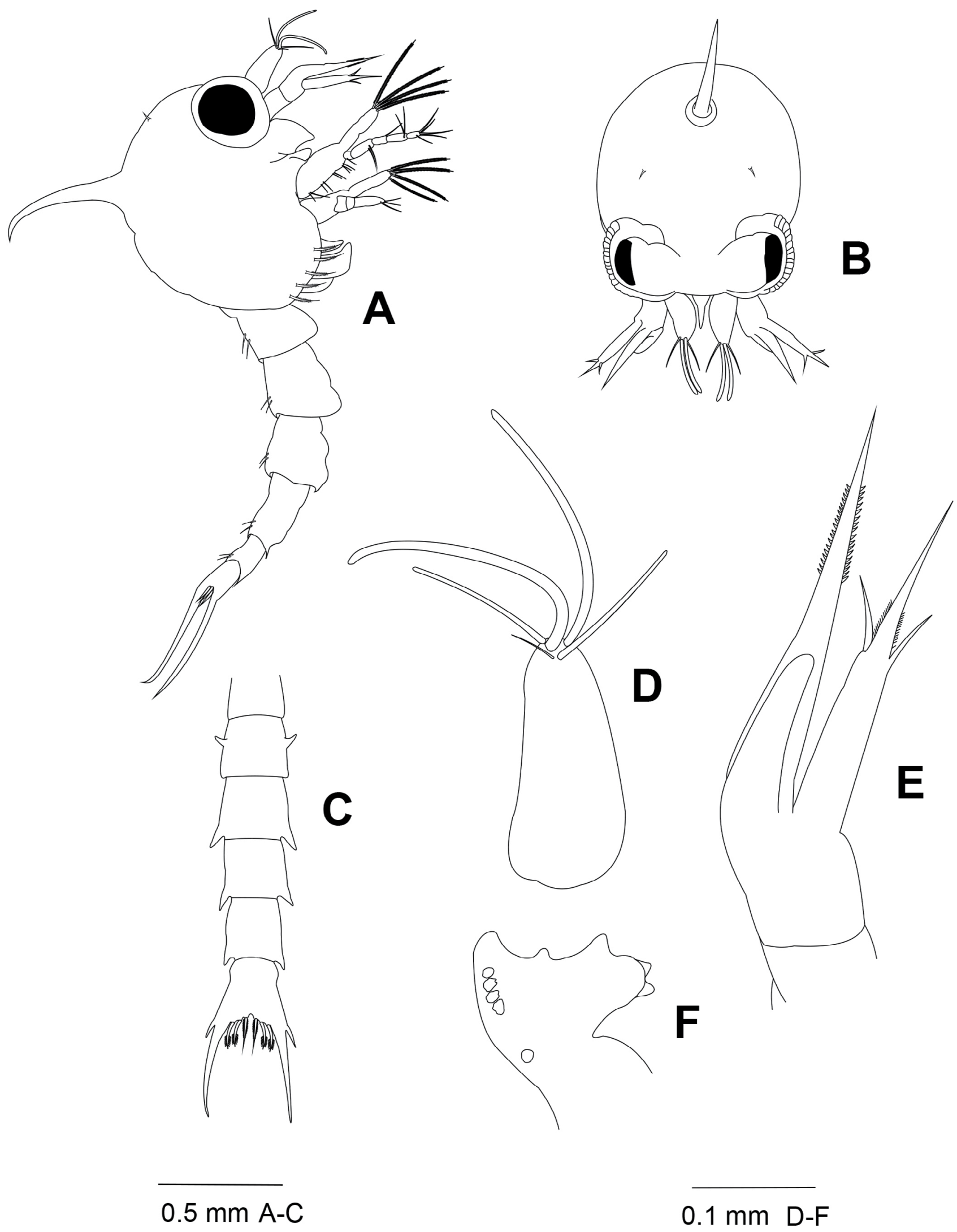

Figure 1. Libinia rhomboidea first zoea. (A) Dorsal view; (B) cephalothorax front view; (C) pleon; (D) antennule; (E) antenna; (F) mandible. 
Cephalothorax (Fig. 3A, B). Size similar to that of former stage; 3 plumose setae at the antero-ventral margin and 3 plumose setae at the postero-ventral margin. Eyes stalked.

Pleon (Fig. 3A, C). Six somites. Somite 2 with pair of dorsolateral processes. Somites $2-5$ with 2 pleopod buds ventrally. Abdominal somite 6 separated from telson and without postero-lateral spines. Telson bifurcated, posterior margin with 3 pairs of spinulate setae. Furcae with only lateral spines.

Pleopods (Fig. 3C). Rudimentary (buds).
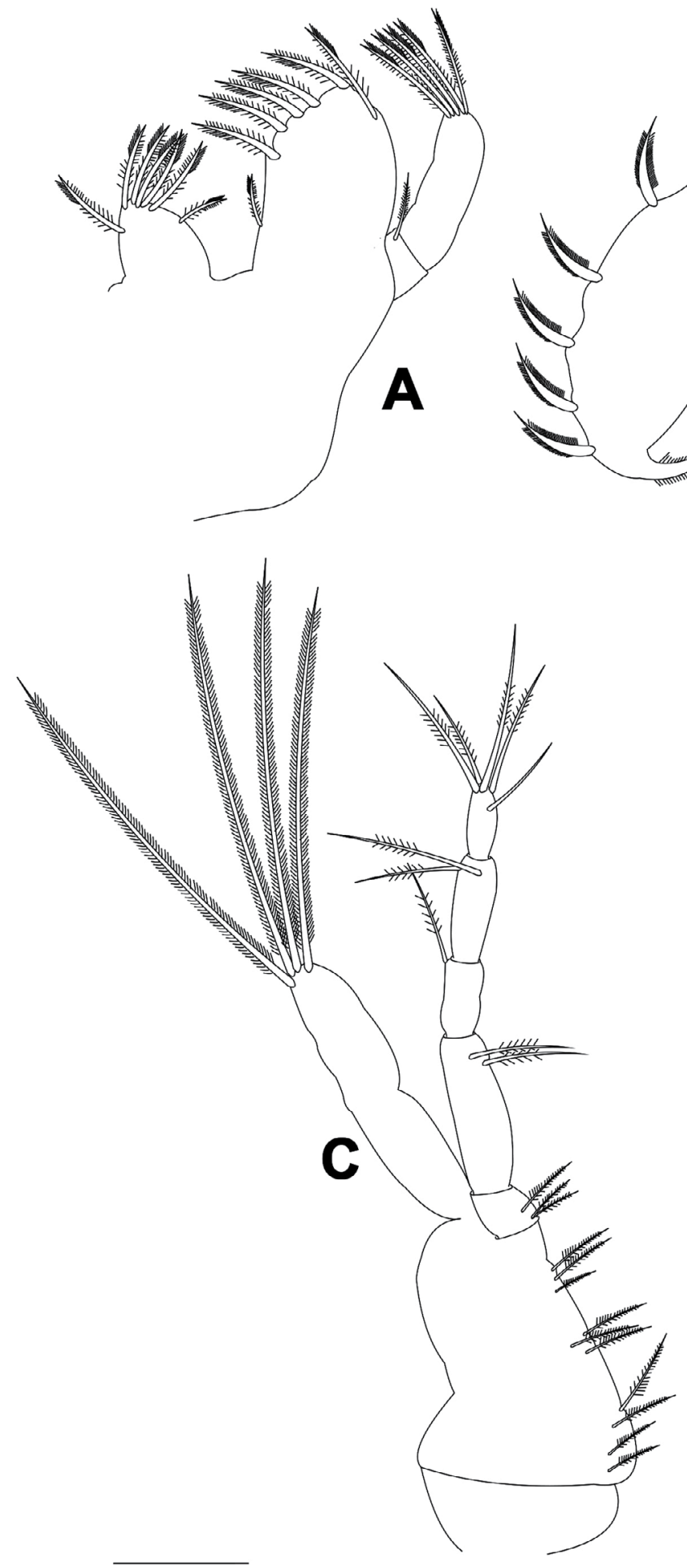

$0.1 \mathrm{~mm}$ A-D
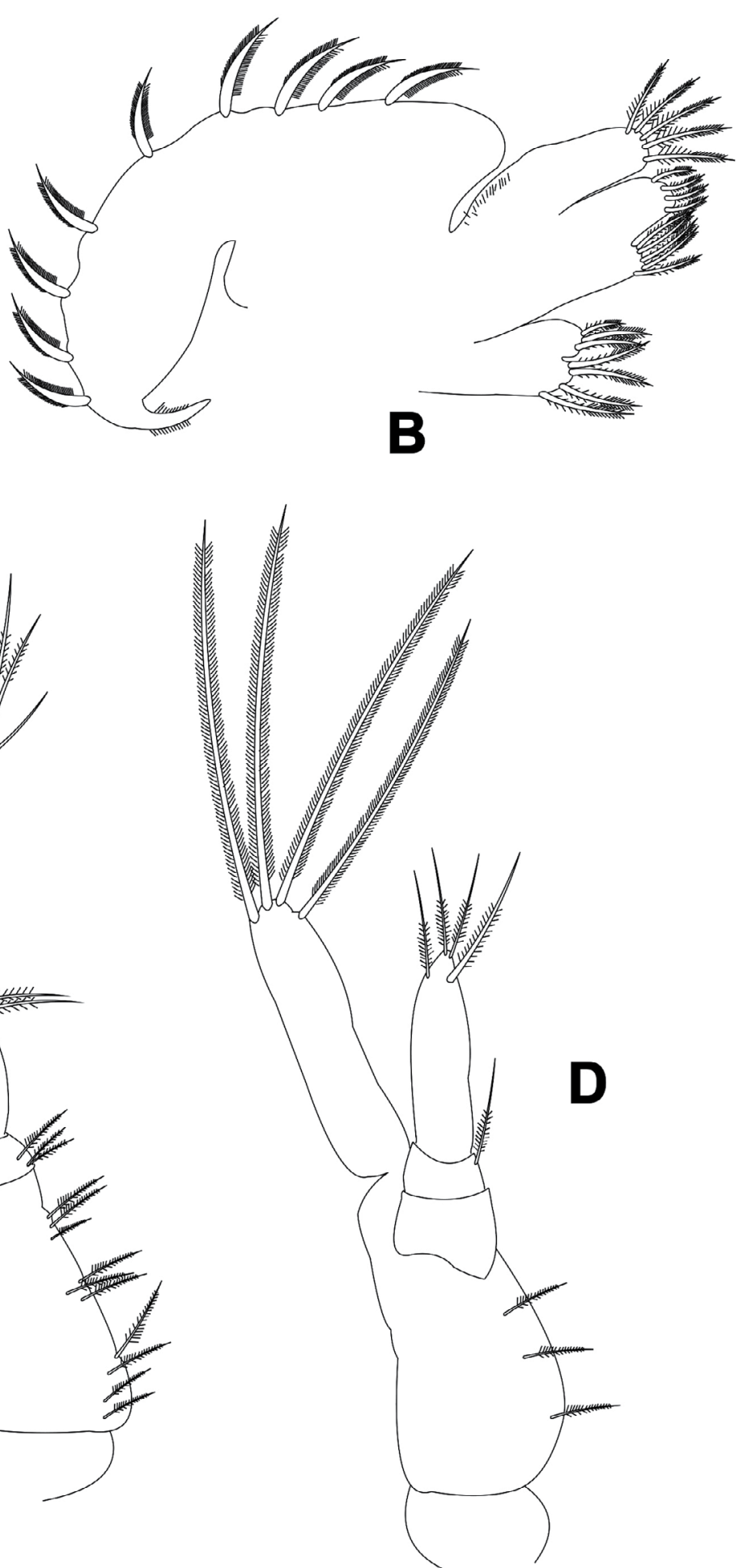

Figure 2. Libinia rhomboidea first zoea. (A) Maxillule; (B) maxilla; (C) first maxilliped; (D) second maxilliped. 
Antennule (Fig. 3D). Similar to that of former stage. Exopod unsegmented with 6 aesthetascs and 1 simple terminal seta.

Antenna (Fig. 3 E). Similar to that of former stage. Endopod bud $0.75 \times$ length of protopod.

Mandible (Fig. 3F). Palp-bud apparent on anterodorsal surface.

Maxillule (Fig. 4 A). Coxal endite with 4 sparsely plumose terminal setae and 3 sparsely plumose subterminal setae. Basial endite with 7 terminal plumodenticulate and 2 sparsely plumose subterminal setae. Endopod 2-segmented, proximal segment with 1 sparsely plumose seta, distal segment with 4 sparsely plumose distal terminal setae and 1 sparsely plumose subterminal seta.

Maxilla (Fig. 4B). Similar to that of former stage. Endopod unlobulated, 5 sparsely plumose terminal setae, microtrichia on external margins. Scaphognathite with 25 plumose setae and a plumose apical tip.

First maxilliped (Fig. 4C). Similar to that of former stage. Endopod 5-segmented with 3, 2, 1, 2, 5 sparsely plumose setae. Exopod 2-segmented, distal segment with 6 long plumose, natatory, terminals setae.

Second maxilliped (Fig. 4D). Similar to that of former stage. Endopod 3-segmented, with 0, 1, 4 sparsely plumose setae. Exopod 2-segmented, with 6 long plumose, natatory, setae.

Third maxilliped (Fig. 4A). Rudimentary.

Pereiopods (Fig. 4A). Rudimentary.

Megalopa (Figs. 5 - 7)

Size. $\mathrm{TL}=2.41 \pm 0.06 \mathrm{~mm} ; \mathrm{CL}=1.24 \pm 0.07 \mathrm{~mm}$; $\mathrm{RL}=0.37 \pm 0.02 \mathrm{~mm}$; CW $0.80 \pm 0.03 \mathrm{~mm}$.

Cephalothorax (Fig. 5A, B). Rostral spine present, rounded at tip and deflected downward, rostral spine length shorter than the length of the antennae. Anterodorsal region, posterior and ventral margins without setae. Eyes sessile. Gastric region with ridges on each side and divided by shallow transverse groove; posterior carination higher than anterior. Cardiac region with small ridge on each lateral side and with a median protuberance, the highest point on carapace. Hepatic lobes somewhat hemispherical in shape. Carapace setation (simple setae): 2 on anterolateral margins of orbital region, 3 on lateral margins of mid-orbital region, $8-10$ on posterior part of front,
4 between anterior gastric carination, 2 between posterior gastric carination, 1 on each posterior gastric carination, 2 anterior to and 2 posterior to cardiac median protuberance, 1 on each lateral cardiac ridge, 1 on lateral margin of each hepatic lobe, numerous setae on posterior margin of carapace.

Pleon (Fig. 5A, B). 6 pleonites plus telson. Abdominal setation (simple setae): somite 1, two setae on postero-dorsal margin; somites 2 and 3, two setae on mid-dorsal surface and four on postero-dorsal margin; somites 4 and 5, six setae on postero-dorsal margin; somite 6, two setae on postero-dorsal margin; telson, two setae on mid-dorsal surface.

Antennule (Fig. 5A, C). Peduncle 3-segmented; from proximal to distal with $0,2,1$ simple setae. Inner flagellum unsegmented, 3 simple terminal setae. Dorsal flagellum 3-segmented; proximal segment bare, penultimate segment with 6 aesthetascs and 1 small dorsal simple seta, distal segment with 6 aesthetascs and 1 large simple subterminal seta.

Antenna (Fig. 5A, D). Peduncle 3-segmented; basal article with 1 dorsal seta, the following 2 distal segments with 2 and 3 simple setae, respectively. Flagellum 4-segmented; proximal and antepenultimate segments bare, penultimate segment with 4 simple subterminal setae, distal segment with 3 long simple terminal setae.

Mandible (Fig. 5E). Palp 3-segmented; distal segment with 5 plumose setae. Masticatory process rounded.

Maxillule (Fig. 6A). Coxal endite with 10 plumodenticulate setae (7 terminal +3 subterminal). Basial endite with 16 setae (7 terminal plumodenticulate, 6 sparsely plumose and 3 subterminal plumodenticulate). Endopod unsegmented, 3 large sparsely plumose setae.

Maxilla (Fig. 6B). Coxal endite bilobed, $3+5$ plumodenticulate setae. Basial endite bilobed, $5-6$ $+6-7$ plumodenticulate setae. Endopod simple, with 1 simple terminal seta. Scaphognathite with $28-30$ plumose marginal setae and 3 inner simple setae.

First maxilliped (Fig. 6C). Coxal endite with 6-7 plumodenticulate setae. Basial endite with $10-11$ plumodenticulate setae. Endopod unsegmented, with 3 sparsely plumose terminal setae. Epipod with 3 - 5 long plumose setae. Exopod 2-segmented; proximal segment with 1 sparsely plumose terminal seta, distal segment with 4 long sparsely plumose terminal setae. 


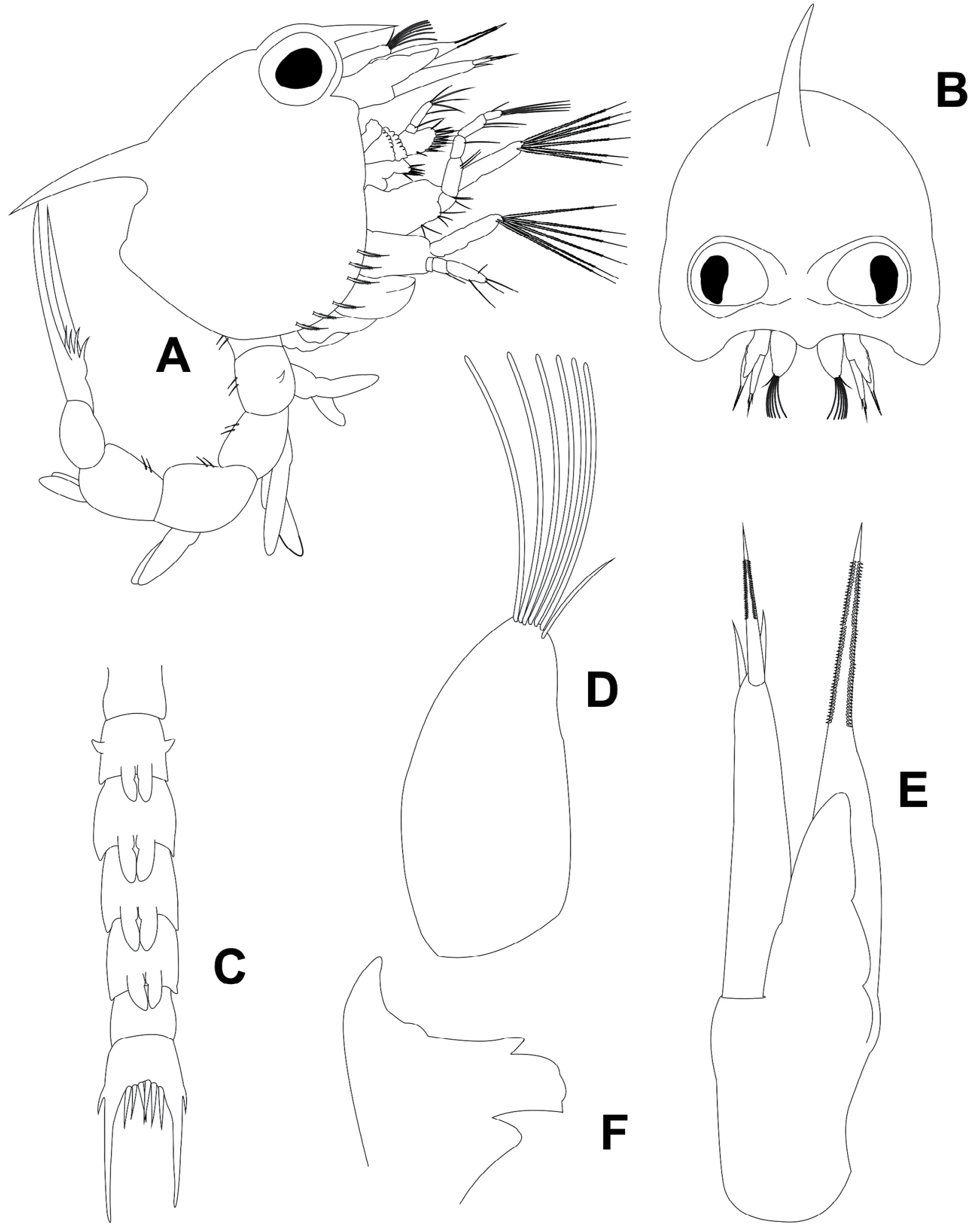

$0.5 \mathrm{~mm} \mathrm{A-C}$

$0.1 \mathrm{~mm} \mathrm{D-F}$

Figure 3. Libinia rhomboidea second zoea. (A) Dorsal view; (B) cephalothorax front view; (C) pleon; (D) antennule; (E) antenna; (F) mandible. 


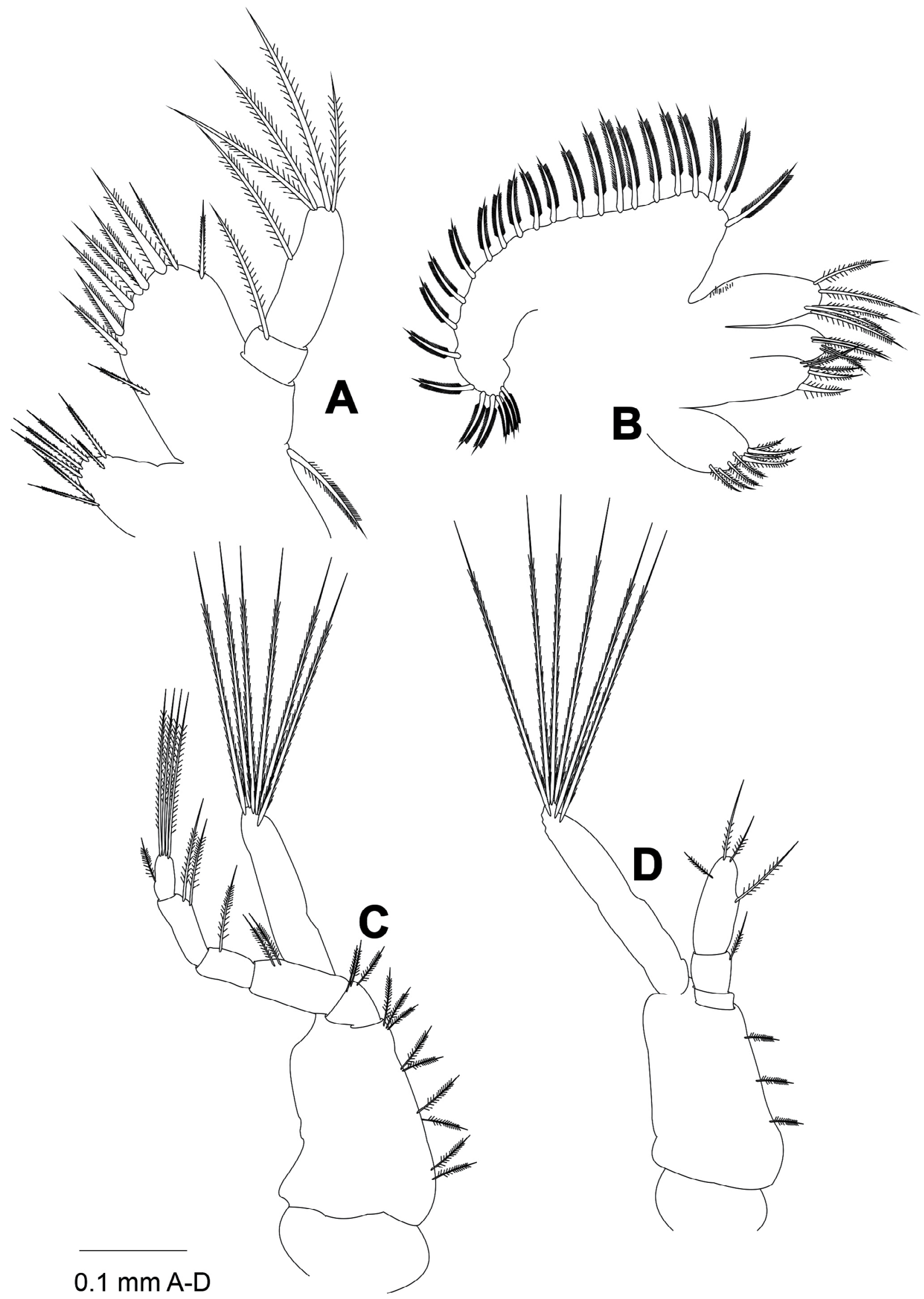

Figure 4. Libinia rhomboidea second zoea. (A) Maxillule; (B) maxilla; (C) first maxilliped; (D) second maxilliped. 
Second maxilliped (Fig. 6D). Endopod 4-segmented, with 0, 1, 3, 6 sparsely plumose setae (proximal to distal segment). Exopod 2-segmented; distal segment with 4 long plumose terminal setae. No epipod present.

Third maxilliped (Fig. 6E). Coxal-epipod with 9 - 10 sparsely plumose setae. Epipod with 4 large plumose setae. Exopod 2-segmented; distal segment with 4 long plumose setae and 2 smaller simple terminal setae. Endopod 5-segmented with 9 - 10,
$8-9,6-7,6,4$ (proximal to distal) sparsely plumose setae, crista dentata with 4 teeth.

Pereopod 1 to 5 (Fig. 7A-E). Moderately setose, cheliped similar to adult form (Fig. 4A).

Pleopod 2-5 and uropods (Fig. 7F - J). Exopod 2-segmented; plumose swimming setae on distal segments as follows: 8 (terminal) +1 (subterminal), $10+1,10+1,8+1$, and uropods with 5 . Endopod of pleopod 2 to 5 small, with 2 small subterminal hooks; uropods without endopod.

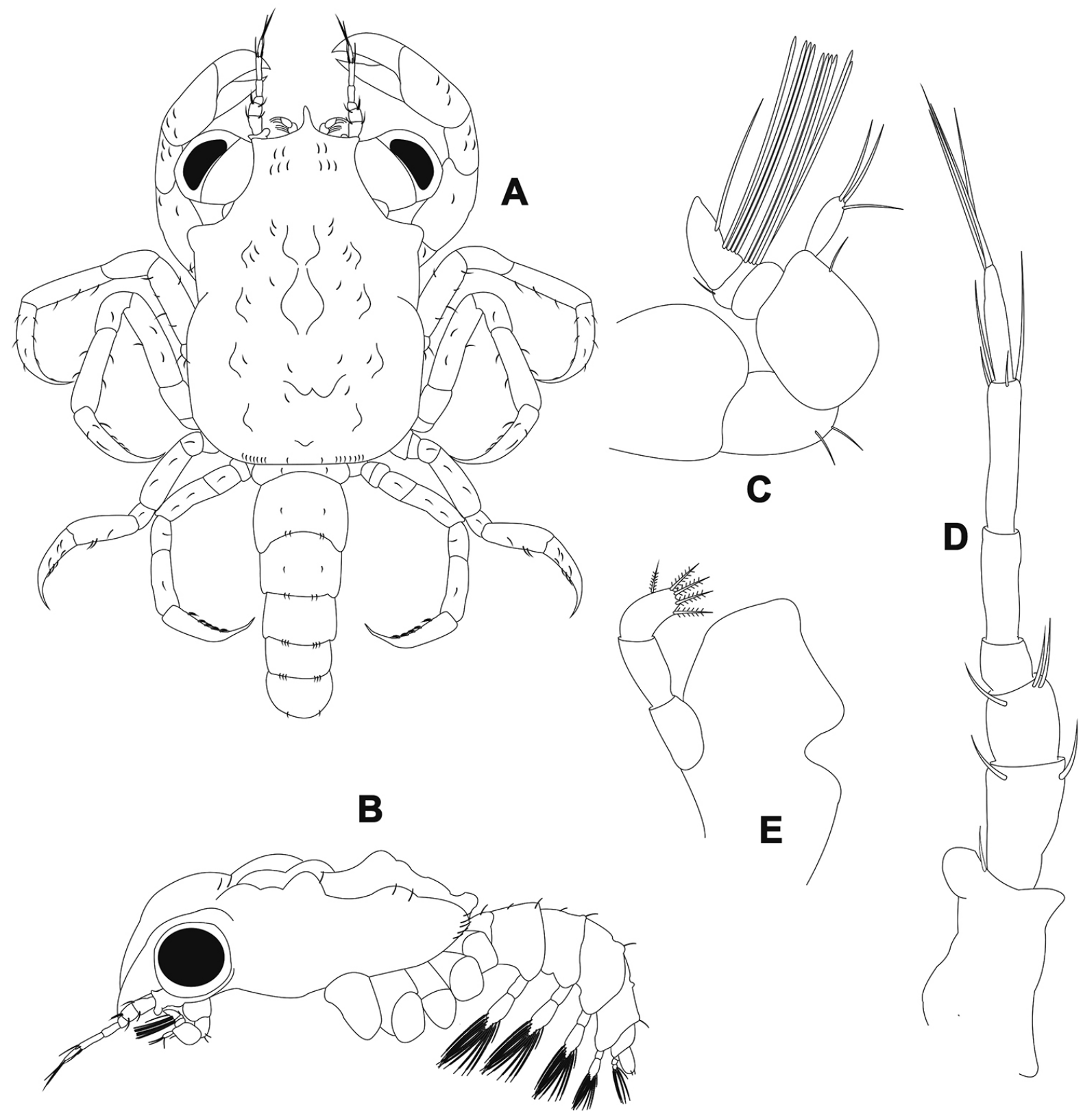

Figure 5. Libinia rhomboidea megalopa. (A) Dorsal view; (B) lateral view; (C) antennule; (D) antenna; (E) mandible. 


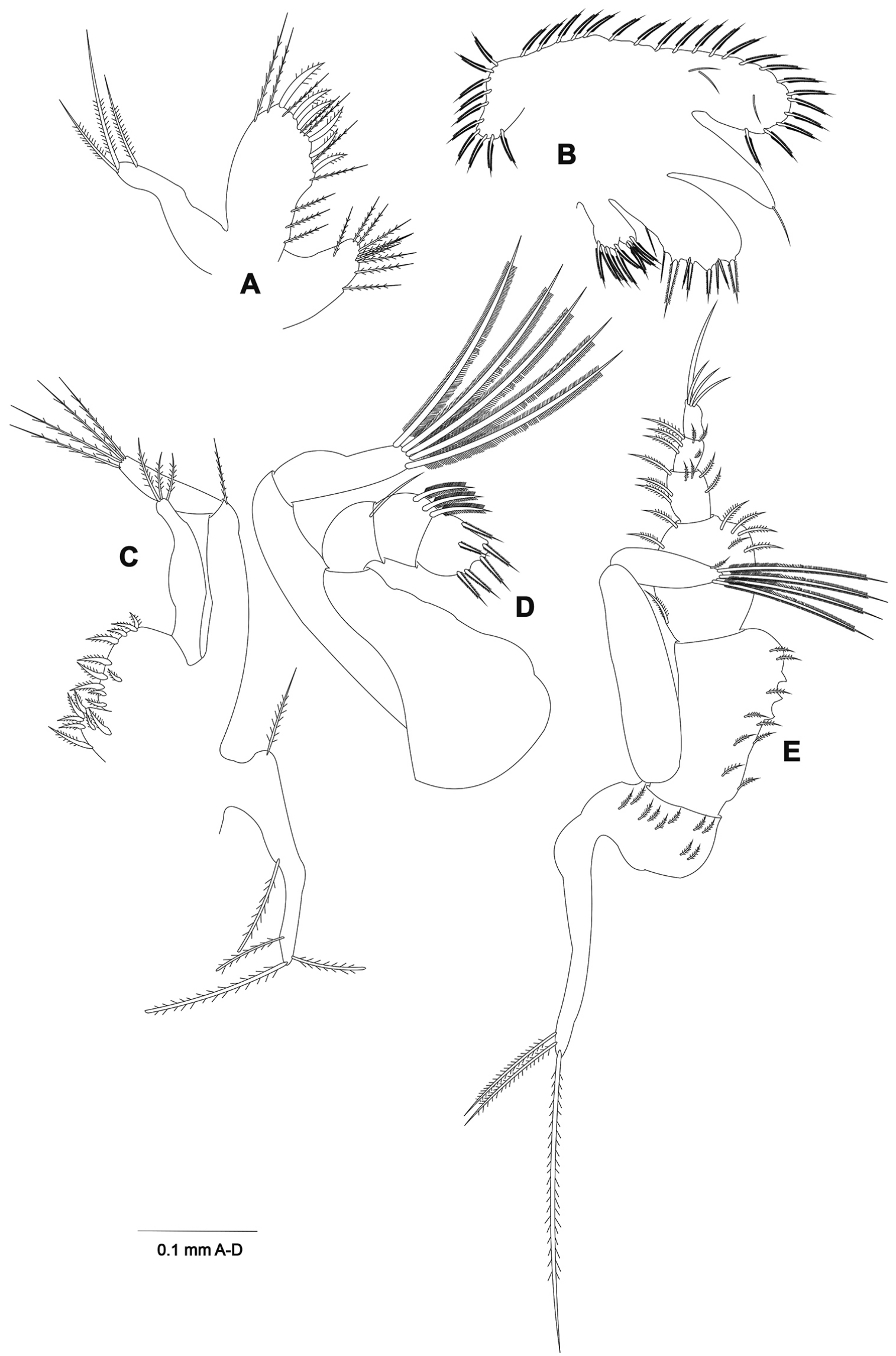

Figure 6. Libinia rhomboidea megalopa. (A) Maxillule; (B) maxilla; (C) first maxilliped; (D) second maxilliped; (E) third maxilliped. 

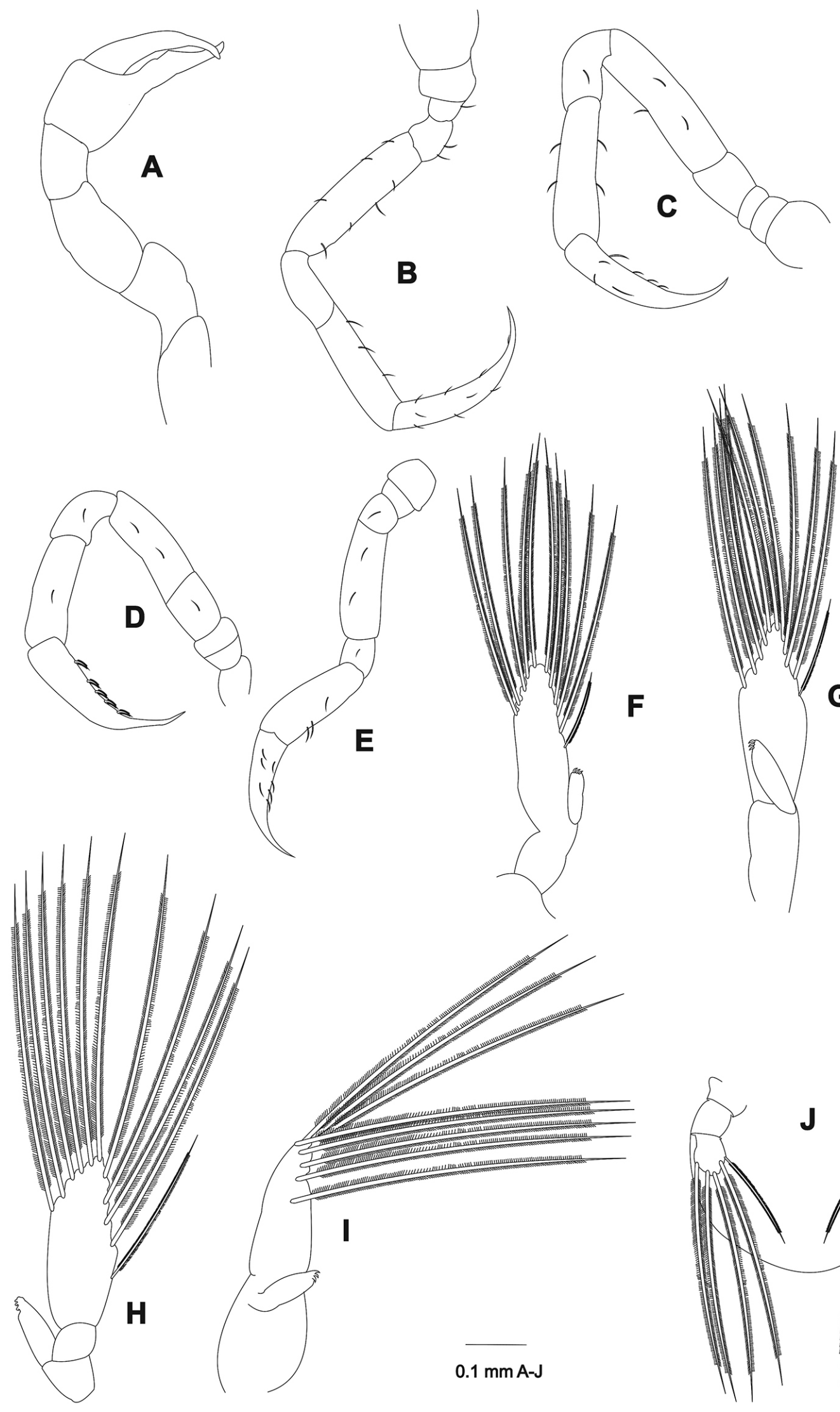

$\mathbf{F}$
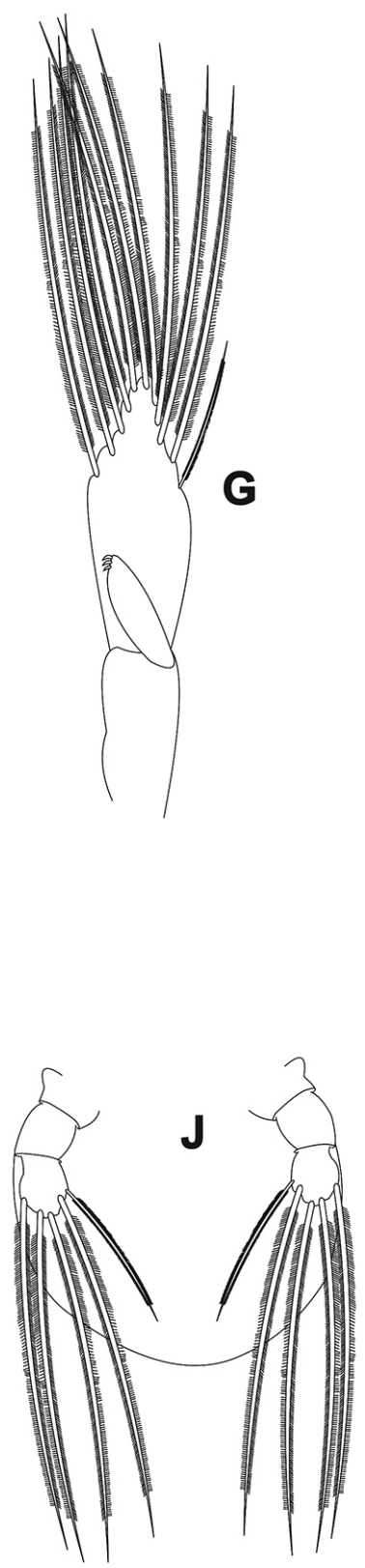

Figure 7. Libinia rhomboidea megalopa. (A) Cheliped; (B) pereiopod 2; (C) pereiopod 3; (D) pereiopod 4; (E) pereiopod 5; (F) pleopod 1; (G) pleopod 2; (H) pleopod 3; (I) pleopod 4; (J) uropod and telson 


\section{Discussion}

In the present study larvae developed optimally because the ovigerous female L. rhomboidea were collected from January to May 2018 at temperatures that represent the mean temperature during the larval season, as is mentioned by Johns and Lang (1977).

Planktonic larvae of Libinia spp. have been found in samples taken from the mouth of Chesapeake Bay to lower York River in waters of $15.74-32.34$ psu salinity and $20-28.1^{\circ} \mathrm{C}$ temperature (Sandifer, 1973). On the other hand, Shanks (1998) reported the presence of megalopae of Libinia spp. in water temperatures of 15 $20^{\circ} \mathrm{C}$ and salinity of $24-35$ psu at the Army Corps of Engineers' Field Research Facility pier in Duck, North Carolina. Bursey (1982) described L. emarginata and L. dubia as moderately euryhaline, they survive 21 49 psu sea water. In natural environments, adults of L. emarginta have been found in a salinity range of 15 - 32 psu (Winget et al., 1974) and they are common to temperatures between 10 and $20^{\circ} \mathrm{C}$ (O'Brien et al., 1999). The above is consistent with the salinity and temperature data recorded in this work (20.5 $22.0^{\circ} \mathrm{C}$ and 32 and $35 \mathrm{psu}$ ) for L. rhomboidea. These are also close to the values reported by Sandifer and van Engel (1971) for the cultivation of L. dubia, who maintained values of $25.5-28.5^{\circ} \mathrm{C}$ and 22 psu salinity, as well as those reported by Johns and Lang (1977) for the cultivation L. emarginata, with values of $25^{\circ} \mathrm{C}$ and 30 psu salinity in South Carolina and values of $20^{\circ} \mathrm{C}$ and 30 psu salinity in Rhode Island.

The duration of development within the genus Libinia is related to temperature, at $20^{\circ} \mathrm{C}$ the development of Libinia spinosa $\mathrm{H}$. Milne Edwards in Guérin, 1832 required from 20 - 30 days (Boschi and Scelzo, 1968), while L. erinace and L. emarginata required 14 days (Yang, 1967; Johns and Lang, 1977). Temperatures above $25^{\circ} \mathrm{C}$ decrease the time of larval development: at $25.5-28.5^{\circ} \mathrm{C} \mathrm{L}$. dubia and L. erinacea only needed 9 days (Yang, 1967; Sandifer and Van Engel, 1971). In this study we found that the time required to complete the development of $L$. rhomboidea larvae was 13 to 14 days at a temperature of $20-22^{\circ} \mathrm{C}$.

Majoid larval development includes only two zoeae stages and one megalopa stage (Luppi and Spivak, 2016). Rice (1980) mentioned that the majoid zoeae could be distinguished from most other brachyurans in having no lateral carapace spine, no lateral process on the third abdominal somite, and a telson fork with a single lateral spine. Consistent with the above, $L$. rhomboidea is a species-typical for the superfamily Majoidea (Gurney, 1942; Hart, 1960). It is important to mention here that the zoeal morphology of a large number of species supports the conclusions from phylogenetic relationships, even more accurately than adult morphology, since the zoeae live in a uniform planktonic environment (Clark, 2009). Particularly, the intrapopulation variability in zoeae morphological characteristics of L. rhomboidea is low. In this regard, other brachyuran species present greater variation (Guerao et al., 2006) and this is related to ecological and genetic factors, which largely determine the variability during the ontogenetic process (Guerao et al., 2008).

The larval morphology of species of Majoidea in the families Epialtidae, Inachidae, Inachoididae, Majidae and Oregoniidae has been previously used to propose relationships among families and subfamilies and to construct phylogenies (Luppi and Sivak, 2016). Marques and Pohle (1998) considered the possible phylogenetic relationships among species of the genus Libinia and used characters of the larvae of the genus Pisa Leach, 1814 and Libinia, as representatives of the subfamily Pisinae, in a study of phylogenetic hypotheses. They found that the subfamily was significantly separated, suggesting that they might be paraphyletic.

A morphological comparison between the three Libinia species present in the SW and SE of the Gulf of Mexico and the species L. spinosa, which is distributed in the south Atlantic, was made. The morphological differences of the first zoea of L. rhomboidea with the species in the genus Libinia are that: in the first zoea, the total length and carapace length are greater and the number of setae on basial endite of the maxillula is different; in the second zoea the size of the endopod and the number of setae in the scaphognathite of the maxilla are greater (Tabs. 1, 2).

The megalopae of L. dubia, L. emarginata, and $L$. rhomboidea all lack a dorsal spine, while L. spinosa has a distinct dorsal spine, which curves posteriorly (Boschi and Scelzo, 1968). The median cardiac protuberance of L. dubia megalopa is single (Sandifer 
Table 1. First zoea of Libinia spp. Character comparison of four species. ND, not described; Nm, not mentioned; $\left(^{*}\right)$ obtained from the figure. Bold type indicates observed differences.

\begin{tabular}{|c|c|c|c|c|c|}
\hline Structure & Character & $\begin{array}{c}\text { L. spinosa } \\
\text { (see Boschi and } \\
\text { Scelzo, 1968) }\end{array}$ & $\begin{array}{c}\text { L.dubia } \\
\text { (see Sandifer and } \\
\text { Van Engel, 1971) }\end{array}$ & $\begin{array}{l}\text { L. emarginata } \\
\text { (see Johns and } \\
\text { Lang, 1977) }\end{array}$ & $\begin{array}{r}\text { L. rhomboidea } \\
\text { (Current study) }\end{array}$ \\
\hline \multicolumn{6}{|l|}{ Cephalothorax } \\
\hline & Total length (mm) & 2.3 & $2.28 \pm 0.26$ & $2.15 \pm 0.15$ & $2.75 \pm 0.05$ \\
\hline & Carapace length & 0.8 & $0.81 \pm 0.05$ & $0.78 \pm 0.02$ & $0.85 \pm 0.05$ \\
\hline & Lateral spines & absent & absent & absent & absent \\
\hline & Length of dorsal spine & $0.59\left(^{*}\right)$ & $0.5\left(^{*}\right)$ & $0.44\left({ }^{*}\right)$ & $0.50 \pm 0.01$ \\
\hline & Length of rostral spine & $0.32\left(^{*}\right)$ & $0.16\left(^{*}\right)$ & $0.11\left({ }^{*}\right)$ & $0.10 \pm 0.01$ \\
\hline & Tip of dorsal to tip of rostral spine & $1.46\left(^{*}\right)$ & $1.25\left(^{*}\right)$ & $1.11\left({ }^{*}\right)$ & $1.45 \pm 0.01$ \\
\hline \multicolumn{6}{|l|}{ Antennule } \\
\hline & Endopod & absent & absent & absent & absent \\
\hline & $\begin{array}{l}\text { Exopod (terminal aesthetascs, small } \\
\text { aesthetascs, simple terminal setae) }\end{array}$ & $4,0,2$ & $2,2,2$ & $2,2,1$ & $2,2,1$ \\
\hline \multicolumn{6}{|l|}{ Antenna } \\
\hline & Protopod (raw spines) & ND & 2 & 2 & 2 \\
\hline & Exopod (raw spines, subterminal spines) & 2,2 & 2,2 & 2,2 & 2,2 \\
\hline & Endopod & bud & bud & bud & bud \\
\hline Mandible (teeth) & & $9(*)$ & 6 & $\mathrm{Nm}$ & 5 \\
\hline & Palp & ND & absent & absent & absent \\
\hline \multicolumn{6}{|l|}{ Maxillule } \\
\hline & $\begin{array}{l}\text { Coxal endite (plumodenticulate terminal setae, } \\
\text { subterminal sparsely plumose setae) }\end{array}$ & $8 \mathrm{~s}$ & $5,2(*)$ & 5,2 & 5,2 \\
\hline & $\begin{array}{l}\text { Basal endite (spines, sparsely plumose } \\
\text { setae, sparsely plumose terminal setae, } \\
\text { plumodenticulate subterminal setae) }\end{array}$ & $4,2,0,0$ & $0,6,0,1$ & $0,2,2,3$ & $0,5,0,2$ \\
\hline & $\begin{array}{l}\text { Endopod (sparsely plumose setae, sparsely } \\
\text { plumose setae) }\end{array}$ & 6 & 1,5 & 1,5 & 1,5 \\
\hline \multicolumn{6}{|l|}{ Maxilla } \\
\hline & Coxal endite (sparsely plumose setae) & 8 & 8 & $7-8$ & $4+3$ \\
\hline & Basial endite (sparsely plumose setae) & 8 & 9 & 10 & $5+4$ \\
\hline & Endopod (terminal setae, microtrichia) & $4-5, \mathrm{Nm}$ & 5 , present & $5, \mathrm{Nm}$ & 5 , present \\
\hline & Scaphognathite (plumose setae, simple seta) & 9,1 & 9 & 9 & 9 \\
\hline \multicolumn{6}{|l|}{ First maxilliped } \\
\hline & Coxa (sparsely plumose seta) & 1 & 0 & 0 & 0 \\
\hline & Basis (sparsely plumose setae) & $2,2,3,3(*)$ & $2,2,3,3$ & $2,2,3,3$ & $2,2,3,3$ \\
\hline & Endopod (sparsely plumose setae) & $3,2,1,2,5\left(^{*}\right)$ & $3,2,1,2,5$ & $3,2,1,2,5$ & $3,2,1,2,5$ \\
\hline & Exopod (terminal plumose setae) & 4 & 4 & 4 & 4 \\
\hline \multicolumn{6}{|l|}{ Second maxilliped } \\
\hline & Coxa (setae) & 0 & 0 & 0 & 0 \\
\hline & Basis (sparsely plumose setae) & $1,1,1$ & $1,1,1$ & $1,1,1$ & $1,1,1$ \\
\hline & Endopod (sparsely plumose setae) & $0,1,4$ & $0,1,4$ & $0,1,4$ & $0,1,4$ \\
\hline & Exopod (terminal plumose setae) & 4 & 4 & 4 & 4 \\
\hline $\begin{array}{l}\text { Third } \\
\text { maxilliped }\end{array}$ & Rudimentary & rudimentary & $\mathrm{Nm}$ & rudimentary & \\
\hline Pereiopods & Rudimentary & rudimentary & $\mathrm{Nm}$ & rudimentary & \\
\hline Pleopods & Absent & absent & $\mathrm{Nm}$ & absent & \\
\hline \multicolumn{6}{|l|}{ Pleon } \\
\hline & Pleonites & 5 & 5 & 5 & 5 \\
\hline & Pleonite 2 (dorsal process) & 2 & 2 & 2 & 2 \\
\hline \multicolumn{6}{|l|}{ Telson } \\
\hline & Furca (lateral spines) & 1 & 1 & 1 & 1 \\
\hline
\end{tabular}


Table 2. Second zoea of Libinia spp. Character comparison of four species. Nm, not mentioned; $\left({ }^{*}\right)$ obtained from the figure. Bold type indicates observed differences.

\begin{tabular}{|c|c|c|c|c|c|}
\hline Structure & Character & $\begin{array}{c}\text { L. spinosa } \\
\text { (see Boschi and } \\
\text { Scelzo, 1968) }\end{array}$ & $\begin{array}{c}\text { L. dubia } \\
\text { (see Sandifer and } \\
\text { Van Engel, 1971) }\end{array}$ & $\begin{array}{c}\text { L. emarginata } \\
\text { (see Johns and } \\
\text { Lang, 1977) }\end{array}$ & $\begin{array}{c}\text { L. rhomboidea } \\
\text { (Current study) }\end{array}$ \\
\hline \multicolumn{6}{|l|}{ Cephalothorax } \\
\hline & Total length (mm) & 2.8 & $2.81 \pm 0.19$ & $2.69 \pm 0.13$ & $2.92 \pm 0.09$ \\
\hline & Carapace length & 0.96 & $0.97 \pm 0.03$ & $0.94 \pm 0.05$ & $1.07 \pm 0.05$ \\
\hline & Lateral spines & absent & absent & absent & absent \\
\hline & Length of dorsal spine & $0.68(*)$ & $0.57\left({ }^{*}\right)$ & $0.38(*)$ & $0.53 \pm 0.02$ \\
\hline & Length of rostral spine & $0.32\left({ }^{*}\right)$ & $0.21\left(^{*}\right)$ & $0.16(*)$ & $0.27 \pm 0.02$ \\
\hline & Tip of dorsal to tip of rostral spine & $1.76\left({ }^{*}\right)$ & $1.43\left({ }^{*}\right)$ & $1.67\left({ }^{*}\right)$ & $1.61 \pm 0.05$ \\
\hline \multicolumn{6}{|l|}{ Antennule } \\
\hline & Endopod & absent & absent & absent & absent \\
\hline & $\begin{array}{l}\text { Exopod (terminal aesthetascs, small aesthetascs, } \\
\text { simple terminal setae) }\end{array}$ & $8,0,3 \mathrm{~s}$ & $4,2,2$ & $2,4,2$ & $4,2,1$ \\
\hline \multicolumn{6}{|l|}{ Antenna } \\
\hline & Protopod (raw spines) & $\mathrm{Nm}$ & 2 & 2 & 2 \\
\hline & Exopod (raw spines, subterminal spines) & 2 & 2 & 2 & 2 \\
\hline & Endopod (extending X of protopod) & bud $(0.5 \mathrm{X})$ & bud $(0.5 X)$ & bud $(0.5 \mathrm{X})$ & bud $(0.75 \mathrm{X})$ \\
\hline Mandible (teeth) & & 9 & 6 & $\mathrm{Nm}$ & 6 \\
\hline & Palp & $\mathrm{Nm}$ & bud & $\mathrm{Nm}$ & bud \\
\hline \multicolumn{6}{|l|}{ Maxillule } \\
\hline & $\begin{array}{l}\text { Coxal endite (sparsely plumose terminal setae, } \\
\text { sparsely plumose subterminal setae) }\end{array}$ & 4,4 & $8 \mathrm{~s}$ & 5,3 & 4,3 \\
\hline & $\begin{array}{l}\text { Basal endite (plumodenticulate terminal setae, } \\
\text { sparsely plumose subterminal setae) }\end{array}$ & 8,2 & 8,2 & 8 & 8,2 \\
\hline & Endopod (sparsely plumose setae) & 1,5 & 1,5 & 1,4 & 1,5 \\
\hline \multicolumn{6}{|l|}{ Maxilla } \\
\hline & Coxal endite (sparsely plumose setae) & 8 & 8 & $7-8$ & 7 \\
\hline & Basial endite (sparsely plumose setae) & 9 & 9 & 10 & 9 \\
\hline & Endopod (terminal setae, microtrichia) & $5, \mathrm{Nm}$ & 5 , present & $5, \mathrm{Nm}$ & 5 , present \\
\hline & Scaphognathite (plumose setae) & 20 & 20 & $16-20$ & $22-24$ \\
\hline \multicolumn{6}{|l|}{ First maxilliped } \\
\hline & Coxa (sparsely plumose setae) & 1 & 0 & 0 & 0 \\
\hline & Basis (sparsely plumose setae) & $2,2,3,3$ & $2,2,3,3$ & $2,2,3,3$ & $2,2,3,3$ \\
\hline & Endopod (sparsely plumose setae) & $3,2,1,2,5$ & $3,2,1,2,5$ & $3,2,1,2,5$ & $3,2,1,2,5$ \\
\hline & Exopod (plumose terminal setae) & 6 & 6 & 6 & 6 \\
\hline \multicolumn{6}{|l|}{$\begin{array}{l}\text { Second } \\
\text { maxilliped }\end{array}$} \\
\hline & Coxa (setae) & $0 \mathrm{~s}$ & $0 \mathrm{~s}$ & $0 \mathrm{~s}$ & $0 \mathrm{~s}$ \\
\hline & Basis (sparsely plumose setae) & $1,1,1$ & $1,1,1$ & $1,1,1$ & $1,1,1$ \\
\hline & Endopod (sparsely plumose setae) & $\mathrm{Nm}$ & $0,1,4$ & $0,1,4$ & $0,1,4$ \\
\hline & Exopod (plumose terminal setae) & 6 & 6 & 6 & 6 \\
\hline Third maxilliped & Rudimentary & rudimentary & $\mathrm{Nm}$ & rudimentary & \\
\hline Pereiopods & Rudimentary & rudimentary & $\mathrm{Nm}$ & rudimentary & \\
\hline Pleopods & buds ventrally & buds ventrally & buds ventrally & buds ventrally & \\
\hline \multicolumn{6}{|l|}{ Pleon } \\
\hline & Pleonites & 6 & 6 & 6 & 6 \\
\hline & Pleonite 2 (dorsal process) & 2 & 2 & 2 & 2 \\
\hline \multicolumn{6}{|l|}{ Telson } \\
\hline & Furca (lateral spines) & 1 & 1 & 1 & 1 \\
\hline
\end{tabular}


and van Engel, 1971) but it is paired in L. emarginata (see Johns and Lang, 1977) and L. rhomboidea. This difference between the megalopae of L. dubia, $L$. emarginata, and L. rhomboidea is relatively clear to observe, however, the difference between zoeae is more subtle and complicated. The characters that make it possible to differentiate L. rhomboidea zoeae from the other three species are: the greater total length and the length of the carapace, as well as the lesser number of setae on the scaphognathite of the maxilla (Tab. 3).

Table 3. Megalopa of Libinia spp. Character comparison of four species. ND, not described; Nm, not mentioned; (*) obtained from the figure. Bold type indicates observed differences.

\begin{tabular}{|c|c|c|c|c|c|}
\hline Structure & Character & $\begin{array}{c}\text { L.spinosa } \\
\text { (see Boschi and } \\
\text { Scelzo, 1968) }\end{array}$ & $\begin{array}{c}\text { L.dubia } \\
\text { (see Sandifer and Van } \\
\text { Engel, 1971) }\end{array}$ & $\begin{array}{c}\text { L. emarginata } \\
\text { (see Johns and Lang } \\
(1977)\end{array}$ & $\begin{array}{l}\text { L. rhomboidea } \\
\text { (Current study) }\end{array}$ \\
\hline \multicolumn{6}{|c|}{ Cephalothorax } \\
\hline & Total length (mm) & 2.1 & $2.12 \pm 0.17$ & $2.12 \pm 0.05$ & $2.41 \pm 0.06$ \\
\hline & Carapace length & 1.3 & $1.14 \pm 0.09$ & $1.22 \pm 0.06$ & $1.24 \pm 0.07$ \\
\hline & Lateral spines & absent & absent & absent & absent \\
\hline & Length of dorsal spine & present & absent & absent & absent \\
\hline & Length of rostral spine (mm) & $0.48\left(^{*}\right)$ & $0.17\left(^{*}\right)$ & $0.2\left(^{*}\right)$ & 0.21 \\
\hline & $\begin{array}{l}\text { Carinations (lateral gastric region, } \\
\text { lateral cardiac region, central gastric } \\
\text { region, central cardiac region, median } \\
\text { border) }\end{array}$ & $\mathrm{Nm}$ & $4,2,0,0,1$ & $4,2,2,2,1$ & $4,2,2,2,1$ \\
\hline \multicolumn{6}{|l|}{ Antennule } \\
\hline & Peduncle (simple setae) & $\mathrm{Nm}$ & $3 \operatorname{seg}(0,2,1)$ & $3 \operatorname{seg}(0,1,1)$ & $3 \operatorname{seg}(0,2,1)$ \\
\hline & Inner flagellum (terminal setae) & 3 & 3 & 3 & 3 \\
\hline & $\begin{array}{l}\text { Dorsal flagellum: proximal (setae); } \\
\text { penultimate (aesthetascs, setae); } \\
\text { distal (aesthetascs, subterminal setae) }\end{array}$ & $0 ; 5,0 ; 6,2$ & $0 ; 6,1 ; 6,1$ & $0 ; 5,0 ; 3,1$ & $0 ; 6,1 ; 6,1$ \\
\hline \multicolumn{6}{|l|}{ Antenna } \\
\hline & Peduncle (segments: simple setae) & $3: 2,2,3$ & $3: 1,2,3$ & $3: 0,1,1$ & $3: 1,2,3$ \\
\hline & Flagellum (segments: simple setae) & $3: 0,3,3$ & $4: 0,0,4,3$ & $4: 0,0,4,3$ & $4: 0,0,3,3$ \\
\hline & Protuberance basal segment & $\begin{array}{l}\text { bud (extending } 0.75 \times \\
\text { basal segment) }\left({ }^{*}\right)\end{array}$ & $\begin{array}{l}\text { bud (extending } 0.3 \times \\
\quad \text { basal segment) }\end{array}$ & $\begin{array}{l}\text { bud (extending } 0.3 \times \\
\quad \text { basal segment) }\end{array}$ & $\begin{array}{l}\text { bud (extending } 0.3 \times \\
\text { basal segment) }\end{array}$ \\
\hline \multicolumn{6}{|l|}{ Mandible } \\
\hline & Palp (segments: setae) & $3: 0,0,5$ & $3: 0,0,5$ & $3: 0,0,5$ & $3: 0,0,5$ \\
\hline \multicolumn{6}{|l|}{ Maxillule } \\
\hline & Coxal endite (plumodenticulate setae) & 10 & $10-11$ & 10 & 10 \\
\hline & Basal endite (plumodenticulate setae) & 16 & $16-17$ & $16-17$ & 16 \\
\hline & $\begin{array}{l}\text { Endopod ( } 1 \text { segment: sparsely plumose } \\
\text { terminal setae) }\end{array}$ & 2 & 2 & $2-3$ & 3 \\
\hline \multicolumn{6}{|l|}{ Maxilla } \\
\hline & Coxal endite (plumodenticulate setae) & $6+6$ & $3+5$ & $3,4+1$ & $3+5$ \\
\hline & Basal endite (plumodenticulate setae) & $6+6$ & $5-6+6-7$ & $12-14$ & $5-6+6-7$ \\
\hline & Endopod (simple terminal setae) & 0 & 1 & 1 & 1 \\
\hline & Scaphognathite (plumose setae) & 30 & $31-32$ & $31-35$ & 28-30 \\
\hline \multicolumn{6}{|c|}{ First maxilliped } \\
\hline & Coxal endite (plumodenticulate setae) & 6 & $5-7$ & 7 & $6-7$ \\
\hline & Basal endite (plumodenticulate setae) & $10-12$ & $10-11$ & $8-10$ & $10-11$ \\
\hline & Endopod (sparsely terminal setae) & $\mathrm{Nm}$ & 3 & $1-3$ & 3 \\
\hline & $\begin{array}{l}\text { Exopod (segments: sparsely plumose } \\
\text { terminal setae) }\end{array}$ & $2: 1,4$ & $2: 0,4$ & $2: 1,5$ & $2: 1,4$ \\
\hline & Epipod (plumose setae) & 4 & $3-5$ & 4 & $3-5$ \\
\hline
\end{tabular}


Table 3. Cont.

\begin{tabular}{|c|c|c|c|c|c|}
\hline Structure & Character & $\begin{array}{c}\text { L. spinosa } \\
\text { (see Boschi and } \\
\text { Scelzo, 1968) }\end{array}$ & $\begin{array}{c}\text { L. dubia } \\
\text { (see Sandifer and Van } \\
\text { Engel, 1971) }\end{array}$ & $\begin{array}{c}\text { L. emarginata } \\
\text { (see Johns and Lang } \\
(1977)\end{array}$ & $\begin{array}{l}\text { L. rhomboidea } \\
\text { (Current study) }\end{array}$ \\
\hline \multicolumn{6}{|c|}{ Second maxilliped } \\
\hline & Endopod (segments: sparsely setae) & $5: 0,0,1,3,7$ & $4: 0,1,3,6$ & $4: 0,1,3,6$ & $4: 0,1,3,6$ \\
\hline & $\begin{array}{l}\text { Exopod (segments: terminal plumose } \\
\text { setae) }\end{array}$ & $2: 0,4$ & $2: 0,4$ & $2: 0,5-6$ & $2: 0,4$ \\
\hline \multicolumn{6}{|l|}{ Third maxilliped } \\
\hline & Endopod (segments: setae) & $5: 10,5,5,4,4$ & $5: 11-12,8-9,5,6,4$ & $5: 9-10,7-8,4,6,4$ & $5: 9-10,8-9,6-7,6,4$ \\
\hline & $\begin{array}{l}\text { Exopod (segments: setae, terminal } \\
\text { plumose setae + simple setae) }\end{array}$ & $2: 0,4+2$ & $2: 0,4+2$ & $2: 0,3-4+2$ & $2: 0,4+2)$ \\
\hline & Crista dentata (teeth) & $\mathrm{ND}$ & 4 & 4 & 4 \\
\hline & $\begin{array}{l}\text { Epipod (subterminal setae }+ \text { terminal } \\
\text { setae) }\end{array}$ & $3+3$ & $4-5$ & $3+3$ & $2+2$ \\
\hline Pereiopods $1-5$ & & - & sparsely setose & sparsely setose & sparsely setose \\
\hline Pleopods 2-6 & (terminal plumose setae) & $10+1,11+1,10,10,5$ & $\begin{array}{c}10+2,10+1,10+1 \\
8+1,5\end{array}$ & $\begin{array}{l}\text { pleopod 2: 11s; } \\
\text { pleopod 5: } 8 \mathrm{~s}\end{array}$ & $\begin{array}{c}8+1,10+1,10+1 \\
8+1,5\end{array}$ \\
\hline Pleon & & 6 pleonites & 6 pleonites & 6 pleonites & 6 pleonites \\
\hline Telson & (medial setae) & $\mathrm{Nm}$ & 2 & $\mathrm{Nm}$ & 2 \\
\hline
\end{tabular}

\section{ACKNOWLEDGEMENTS}

The authors wish to thank Ana Paola Rodríguez Carmona for English editing of the manuscript. This research was financially supported by DGAPA, UNAM under the PAPIIT 200118 project.

\section{References}

Boschi, E.E. and Scelzo, M.A. 1968. Larval development of the spider crab Libinia spinosa $\mathrm{H}$. Milne Edwards, reared in the laboratory (Brachyura, Majidae). Crustaceana, Supplement 2: 169-180.

Bursey C.R. 1982. Salinity Tolerance and Osmotic Response in Two Species of Spider Crabs of the Genus Libinia (Decapoda Brachyura, Majidae). Crustaceana, 42: 194-200.

Carmona-Osalde, C. and Rodríguez-Serna, M. 2012. Reproductive aspects of the spider crab Libinia dubia under laboratory conditions. Hidrobiológica, 22: 58-61.

Carmona-Osalde, C.; Pat-López, J.G. and Rodríguez-Serna, M. 2018. Actualización de registros del género Libinia sp. (Crustacea: Decapoda: Brachyura: Majoidea) en las costas de Sisal, Yucatán. Monterrey, Nuevo León, México, XI Reunión Nacional Alejandro Villalobos, p. 29.

Clark, P.F. 2009. The bearing of larval morphology on Brachyuran Phylogeny. p. 221-241. In: J.W. Martin; K.A. Crandall and D.L. Felder (eds), Decapoda Crustacea Phylogenetics. Crustacean Issues 18. Lafayette, CRC Press, 567p.

Clark, P.F.; Calazans, D.K. and Pohle, G.W. 1998. Accuracy and standardization of brachyuran larval descriptions. Invertebrate Reproduction and Development, 33: 127-144.

Clark, P.F. and Cuesta J.A. 2015. Larval systematics of Brachyura. p. 981-1048. In: P. Castro; P.J.F. Davie; D. Guinot; F.R.
Schram and J.C. von Vaupel-Klein (eds), Treatise on ZoologyAnatomy, Taxonomy, Biology. The Crustacea, Vol. 9, Part C. Leiden, Brill.

Comisión Nacional para el Conocimiento y Uso de la Biodiversidad (CONABIO). 2010. Ficha técnica para la evaluación de los sitios prioritarios para la conservación de los ambientes costeros y oceánicos de México. Humedales costeros y Plataforma continental de Cabo Catoche. Mesa de Trabajo: Golfo de México (Ecorregión Nivel - I CCA: Golfo de México Sur; Categoría del sitio: Zona costera).7p. Available at http:/ / www.conabio.gob.mx/gap/images/2/20/68_Humedales_

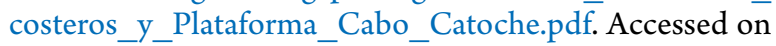
20 January 2020.

Ehrenberg, C.G. 1844. Einige vorläufige Resultate seiner Untersuchungen der ihm von der Südpolreise des Capitain Rofs, so wie von den Herren Schayer und Darwin zugekommenen Materialien über das Verhalten des kleinsten lebens in den Oceanen und den gröfsten bisher zugänglichen Tiefen des Weltmeers. Bericht über die zur Bekanntmachung geeigneten Verhandlungen der Königlich-Preussischen Akademie der Wissenschaften zu Berlin, 1844: 182-207.

Felder, D.L.; Álvarez, F.; Goy, J.W. and Lemaitre, R. 2009. Decapoda (Crustacea) of the Gulf of Mexico, with comments on the Amphionidacea. p. 1019-1104. In: D.L. Felder and D.K. Camp (eds), Gulf of Mexico Origin, Waters, and Biota. Volume 1, Biodiversity. College Station, Texas Texas A\&M University Press.

Gomont, M. 1892. Monographie des Oscillariées (Nostocacées Homocystées). Deuxième partie. Lyngbyées. Annales des Sciences Naturelles, Botanique, 7: 91-264.

Gonçalves, G.R.L.; Bolla, E.B. Jr.; Negreiros-Fransozo, M.L. and Castilho, A.L. 2016. Morphometric and gonadal maturity of the spider crab Libinia ferreirae Brito Capello, 1871 (Decapoda: Majoidea: Epialtidae) at Southeastern Brazilian coast. Journal of the Marine Biological Association of the United Kingdom, 97 (for 2017): 289-295. 
Guerao, G.; Abello, A. and dos Santos A. 2006. Morphological variability of the megalopa of Liocarcinus depurator (Brachyura: Portunidae) in Mediterranean and Atlantic populations. Journal of Natural History, 40: 1851-1866.

Guerao, G.; Pastor, E.; Martin J.; Andrés, M.; Estévez, A.; Grau A.; Duran, J. and Rotllant, G. 2008. The larval development of Maja squinado and M. brachydactyla (Decapoda, Brachyura, Majidae) described from plankton collected and laboratoryreared material. Journal of Natural History, 42: 2257- 2276.

Gurney, R. 1942. Larvae of decapod Crustacea. London, Ray Society, i-vii+306p.

Hart, J.F.L. 1960. The larval development of British Columbia Brachyura. n. Majidae, Subfamily Oregoniinae. Canadian Journal of Zoology, 38: 539-546.

Hultgren, K. and Stachowicz, J. 2011. Camouflage in decorator crabs. p. 214-238. In: M. Stevens and S. Merilaita (eds), Animal Camouflage: Mechanisms and Function. Cambridge, Cambridge University Press.

Johns, D.M. and Lang, W.H. 1977. Larval development of the spider crab, Libinia emarginata (Majidae). Fishery Bulletin, 75: 831-841.

Leach, W.E. 1815. The zoological miscellany; being descriptions of new, or interesting animals, illustrated with coloured figures, drawn from nature. Vol. 2. Covent Garden and London, E. Nodder and Son, 154p., pls. 61-120.

Leach, W.E. 1819. Entomostraca, Dictionaire des Science Naturelles, vol. 14, p. 524. Paris, Levrault and Schoell.

Luppi, T.A. and Spivak, E.D. 2016. The larval development of the spider crab Rochinia gracilipes (Crustacea: Majoide: Epialtidae: Pisinae) reared in laboratory. Journal of Natural History, 50: 1983-2003.

Marques, F. and Pohle, G. 1998. The use of structural reduction in phylogenetic reconstruction of decapods and a phylogenetic hypothesis for 15 genera of Majidae: testing previous larval hypotheses and assumptions. Invertebrate Reproduction and Development, 33: 241-262.

Milne-Edwards, H. 1834-1837. Histoire naturelle des Crustacés comprenant l'anatomie, la physiologie et la classification de ces animaux. Vols. 1, 2, Atlas. Paris, Librairie Encyclopédique de Roret.

Milne-Edwards, A. 1879. Études sur les Crustacés Podophtalmaires de la région méxicaine. In: Mission Scientifique Du Mexique et dans l'Amérique Centrale. Recherches zoologiques pour servir à l'Histoire de la faune de l'Amérique Centrale et $\mathrm{Du}$ Mexique. Paris, Ministère de l'Instruction Publique. Vol. 5, p. 185-264.
Nogueira Jr., M. and Haddad, M.A. 2005. Lychnorhiza lucerna (Scyphozoa, Rhizostomeae) and Libinia ferreirae Brito Capello (Brachyura, Majidae) association in southern Brasil. Revista Brasileira de Zoologia, 22: 908-912.

O’Brien, S.B.; Landau, M. and Able K.W. 1999. Sex ratios of two species of spider crabs, Libinia dubia H. Milne Edwards, 1834 and L. emarginata Leach, 1815, in the area of Great Bay, New Jersey. Crustaceana, 72: 187-192.

Rice, A. L. 1980. Crab zoeal morphology and its bearing on the classification of the Brachyura. Transactions of the Zoological Society of London, 35: 271-424.

Sandifer, P.A. and van Engel, W.A. 1971. Larval development of the spider crab, Libinia dubia H. Milne Edwards (Brachyura, Majidae, Pisinae), reared in laboratory culture. Chesapeake Science, 12: 18-25.

Sandifer, R.A. 1973. Distribution and abundance of decapod crustacean larvae in the York River estuary and adjacent lower Chesapeake Bay, Virginia, 1968 - 1969. Chesapeake Science, 14: 235-257.

Shanks, A.L. 1998. Abundance of post-larval Callinectes sapidus, Penaeus spp., Uca spp., and Libinia spp. collected at an outer coastal site and their cross-shelf transport. Marine Ecology Progress Series, 168: 57-69.

Stein, F.R. 1878. Der Organismus der Infusionstiere, III, 1. Hälfte Flagellaten. Leipzig, edited by Engelmann.

Streets, T.H. 1870. Notice of some Crustacea of the genus Libinia, with descriptions of four new species. Proceedings of the Academy of Natural Sciences of Philadelphia, 22: 104-107.

Williams, A.B.; Shaw, J.K. and Hopkins, T.S. 1977. Stilbomastax, a new genus of spider crab (Majidae: Tychinae) from the west indies region, with notes on American relatives. Proceedings of the Biological Society of Washington, 90: 884-893.

Winget, R.R.; Maurer, D. and Seymour, H. 1974. Occurrence, size composition and sex ratio of the rock crab. Cancer irroratus Say and the spider crab, Libinia emerginata Leach in Delaware Bay. Journal of Natural History, 8: 199-205.

Yang, W. 1967. A study of zoeal, megalopal and early crab stages of some oxyrhynchous crabs (Crustacea: Decapoda). University of Miami, Miami, Ph.D. Thesis, 459p [Unplublished].

Zaldívar-Rae, J.; Sapién-Silva, R.E.; Rosales-Raya, M. and Brockmann, H.J. 2009. American Horseshoe Crabs, Limulus polyphemus in Mexico: Open Possibilities. p. 97-113. In: J.T. Tanacredi; M.L. Botton and D.R. Smith (eds), Biology and Conservation of Horseshoe Crabs. New York, Springer. 